DOI: https://doi.org/10.31392/NPU-nc.series9.2018.17.07

UDC: $801.82: 82-92: 81 ’ 372$

\section{Olena M. Kolomiiets}

Khmelnitskyi Cooperative Trade and Economic Institute,

Khmelnitskyi, Ukraine

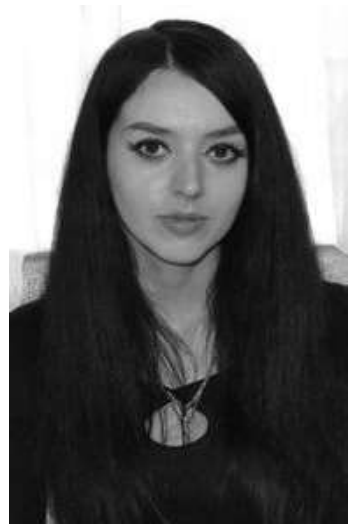

\title{
FIGURATIVE AND STYLISTIC ELEMENTS RECONSTRUCTION OF NEWSPAPER SYNOPTIC TEXTS (Based on the English, German, Polish and Ukrainian languages)
}

\section{Bibliographic Description:}

Kolomiiets, O. M. (2018). Figurative and Stylistic Elements Reconstruction of Newspaper Synoptic Texts (Based on the English, German, Polish and Ukrainian Languages). Scientific Journal of National Pedagogical Dragomanov University. Series 9. Current Trends in Language Development. K. 17. 81-98. DOI: https://doi.org/10.31392 /NPU-nc.series9.2018.17.07

\section{Abstarct}

The article discovered the new methodological possibility of reconstruction, which in cognitive linguistics began to be applied to other, broader tasks associated with the need to restore structures of consciousness, which include newspaper synoptic texts (hereinafter - NST) as mental formations. Active decoding of innersemantic elements of NST revealed stylistic devices based on the interaction of 1) the vocabulary and contextual meanings (metaphor, metonymy, irony), 2) primary and derivative meanings (zeugma, pun), 3) the logical and emotional meanings (epithet, oxymoron), 4) logical and nominative meanings (antonomasia), as well as the one 5) that provide additional characteristics of the object of description (hyperbole, comparison).

It was determined that the primary means of NST based on the interaction of vocabulary and contextual meanings is metaphor and during the process of reconstruction it became possible to divide it into four types: nominative, figured, cognitive and generalized. Three models of determined analogical transformation from the name of the weather phenomena to the result of the name, from the name of action to the action object name, from the name of the piece of weather phenomena to the name of a weather phenomena as well as two directions of semantic reconsideration of the phenomena associated with weather forecasting which are the violation of the ritual and habits of everyday life and the representation of the obscurity of the attitude to the weather phenomena were defined.

The article proves that less productive NST images in the studied languages are those that are based on the interaction of basic and derivative meanings and logical and emotional meanings. Among the most common means of providing additional characteristics to description of hyperbole is revealed which aim is to 
express exaggerated attitude to weather forecast scenario and comparison to appeal to the readers' experience and memory, which helps them to identify the information provided by the author.

Keywords: reconstruction, newspaper synoptic text, figurative and stylistic element, stylistic device, innersemantic elements.

\section{Introduction.}

Modern anthropocentric linguistics returns to the study of those scientific phenomena, which origins reach comparative and historical paradigm. First of all, the notion of reconstruction belongs to such scientific descriptions which in the classical linguistic paradigm (O. Kh. Vostokov, F. Bopp, J. Grimm, R. Rask, etc.) were reduced to the procedural technique of the comparative and historical method to restore the Proto-IndoEuropean etymon (R. F. Adrados, R. V. Boldyrev, L. A. Bulakhovskyi, V. A. Dibo, A. B. Dolgopolsky, A. F. Zhuravlev, V. V. Martynov, O. S. Melnychuk, S. L. Nikolayev, M. I. Tolstoy, V. M. Toporov, O. M. Trubachyov, E. Benveniste, A. Meillet). Nowadays, the term "reconstruction" (L. P. Dronova, A. V. Korolyova, M. O. Shutova, etc.) is understood as the consistent restoration of processes, mechanisms and stages of more complex forms construction (cognitive, semantic, structural, etc.) in particular structures of human consciousness, objectified as units of lexical and semantic system, and of higher-level entities represented by text structures (O. V. Delva, O. O. Cherkhava, D. Crystal, A. Falileyev, G. Hudson, K. MacCone, P. Sims-Williams).

The phenomenon of reconstruction has become an important theoretical and methodological basis of modern linguistic research (G. A. Klimov, G. Bonfante, J. Kurylovich, K. Koerner, H. M. Hoenigswald) connected with the renewed problem study of the language and consciousness connection (A. V. Korolyova, L. P. Dronova, M. O. Shutova, S. Sh. Aytov, P. V. Kretov, O. I. Kretova), language and culture connection (Yu. D. Apresyan, V.Z. Demyankov, V. V. Zhayvoronok, O. D. Krivonosov, Yu. M. Lotman, J. A. Sternin, A. Wierzbicka); world language picture reproduction (I. O. Golubovsky, G. V. Kolshansky, G. V. Mezhzerina, Zh. P. Sokolovsky, O. D. Shmelev), national conceptual spheres composition (N. D. Arutyunova, S. G. Vorkachov, V. I. Karasik, V. I. Kononenko, V. V. Krasny, G. M. Yavorskaya) and others.

The classical understanding of reconstruction is reduced to its interpretation as a procedure of comparative historical method, which aims are to establish an archetype based on the position that sounds' changes in related languages have distinct natural character that is why the word roots and inflections are stable for thousands of years (the founders of comparative historical method the procedure of which is reconstruction were German linguists F. Bopp and J. Grimm).

Comparative historical method remains the most important tool for establishing languages affinity and knowledge of their history, but with the development of linguistic science, the term "reconstruction" began to be interpreted more broadly than just the procedure of comparative and historical method and became an independent method of cognitive comparative linguistics that involves restoring structures of consciousness which are organized as matrices (a founder of cognitive comparative linguistics is A. V. Korolyova), and is the foundation of modern linguistic research. In particular A. V. Korolyova said that today there is a tendency to evolve the term of "reconstruction" from a narrow understanding of the classical Indo-European studies as the reconstruction of ancient language forms and states to the wide sense - as theoretical and methodological problem of studying the original structures (mythological) and modern consciousness based on the theory of categorization, mental theory, cognitive modeling etc. The linguist notes that the main task of cognitive comparative linguistics is the reconstruction of internal human 
cognitive structure in dynamics, where man is regarded as information processing system (consisting of independent components (conceptual spheres)), which is able to correlate information from various linguistic conceptual spheres (Korolyova 2014: 95). Some conceptual spheres are interpreted as varieties of complex unities that intersect and concentrate the experience of their carrier based on both ancient and modern consciousness with the help of language verbalization. Of course, the correlation between the bonds of ancient and modern language consciousness relics brings us back to such phenomena as diachrony and synchrony in their projections for the linguistic structures of conscious organization, and on the diachronic approach of their studies.

Studying the evolution of the concept of reconstruction O. O. Cherkhava notes that the concept of "linguistic reconstruction" has intergraded from reproducing the original roots of words in the narrowest sense (including methodological procedure of sound and morphological systems of languages comparison, grammatical and syntactical correspondences) to the theoretical and semantic laws of the state of similarity genetically related languages, cognitive human processes procedures to the modern large-scale theoretical and methodological approach to the interpretation of the philosophical meaning of entity (Cherkhava 2015: 157).

Reconstruction is the essence of modern comparative linguistic studies that can detect common and different features in languages, representing the concept of different world images of language carriers. However, despite numerous studies within these issues, many problems still remain unsolved, including: text (context) status for implementing semantic reconstruction for interpreting the author's uttering through the reconstruction of his / her intention.

Among the number of modern approaches (anthropocentric, discursive, cognitive, contextual), with the help of which the interpretation of the term "reconstruction" was carried out, special attention deserves discursive approach, because, according to Yu. Lotman study, all the surrounding reality can be described as text, because people through the interaction with whatsoever can make meanings of themselves, their society and express their attitude to it (Lotman 1996: 12). The basis of this approach is to understand the idea of reconstruction as a way of representation and interpretation of reality through its objectification in the light of the text as a sign of culture. Under these conditions, the text (its structure, semantic, syntax) undoubtedly becomes a product and the phenomenon of the society, a reflection of its attitude and outlook. Thus the text serves as a three-pronged sign of complex nature: cultural, mental and verbal.

The universal approach to the definition of the concept was offered by M. P. Brandes, who related structure with the form and as a system of methods, techniques, expression, representation, transformation and operation contents; however, she outlined three aspects: the aspect of outer language form, aspect of feasibility of external forms and information semantic and symbolic aspect. The aspect of outer language form is linked to the speech objectivation of the functional content through the use of linguistic resources (Brandes 2004: 123). Aspect of external shape feasibility embodies the functions of appointment of the text objective content, which is implemented in the form of costruction matter. Informational semantic and symbolic aspect of forms is connected with cultural and historical context.

Emphasizing the text importance for implementing semantic reconstruction linguists note that the text is needed for semantic reconstruction, because only careful study of the text (context) within its fragments, including unit selected for analysis, is necessary and sufficient to determine the value of the unit, which is consistent for the whole meaning of the text, where the studied form is expressed in a variety of use, that can explain and motivate convergence / divergence of the meanings. Implementing the procedure of semantic 
reconstruction, one should remember that even selected meaning of the word from the context is not the only one; other meanings of the word selected exist potentially.

The evolution of the term "reconstruction", which has undergone a long stage of formation from the original forms to text constructs in cognitive linguistics, can be divided into three stages.

At the first stage (F. Bopp, J. Grimm, R. Rask, O. Kh. Vostokov), reconstruction was considered as "the reproduction of the language preforms"; "the formula of correspondence and the real form of language and the purpose of comparison" (F. de Saussur) (Kochergan 2006: 214-215). At the end of the nineteenth and early twentieth centuries, linguists (K. Brugman, B. Delbruck, G. Ostkhov, A. Leshkin, F. Fortunatov, F. Schlegel) linked the reconstruction with the reproduction of the word phonetic image, since the basis of the word phonetic changes are laws that do not know the exceptions. The undoubted achievement of the first stage was the doctrine of language interpretation as a result of psychophysical activity (S. Bugge, M. Breal, K. Werner, V. Thomsen, B. Whitney). According to scientists, speech has two aspects: mental and physical. Therefore, to study the role of mental mechanisms in sound changes, they used the achievements of psychology.

The second stage is characterized by the transition from the word reconstruction to more complex formation reconstruction represented by canonical and historical texts (K. Jackson, C. Menges, O. Shakhmatov, I. Williams). The first attempts to carry out text reconstruction were characterized by indistinctness of linguistic approaches, uncertainty of the reconstruction procedure, but the undoubted achievement was that linguists attempted to link the results of reconstruction with the history and culture.

Linguist O. Shakhmatov, who first attempted to reconstruct the text "Povist' mynulykh lit", commenting on the purpose of the reconstruction claimed: "Linguistic issues during reconstruction should not be in the foreground" (Shakhmatov URL: http://www.studmed.ru/shahmatov-aa-povest-vremennyh[...]). Having analyzed the writing style, the scientist paid more attention to the historical constituent, and connection between language and culture.

Another striking example of text reconstruction was offered by linguists who not only reproduced the canonical text "The Word of the Ihor's Regiment", but also gave authors' interpretation of the lexical composition (some geographical names), the foreign words explanation as the elements of oriental culture (Menhes URL: http://weblib.pp.ua /vostochnyie-elementyi-slove-polku-igoreve.html).

An important aspect of textual reconstruction in the study of intercultural relations was European scholars' achievement based on the results of the Anglo-Saxon heroic epic "Beowulf" reconstruction. Linguist R. Williams recreated the Finnic episode and interpreted it through the system of signs and meanings (Williams 1924: 116-156).

In the well-known book "Language and History in Early Britain" (1953) K. Jackson reconstructed the Neo-Briton language semantics (Jackson 1953: 110-134), and tried to explain it, using historical information about culture and people's life.

Thus, linguists were united in their attempt not only to reconstruct the lexical, morphological, syntactic systems of the original, but also to study the text structure, its semantics and to give their own interpretation to speech phenomena outlining the history reflection and people culture through a series of semantic elements.

The third stage (V. Meyserskyi, B. O. Parakhonskyi, G. Bloom, L. Gray, W. Royder) showed the rethinking of the text reconstruction purpose and procedure. Yu. Lotman, who pointed out that "the whole surrounding reality can be described as text because people in the process of interacting with anything can produce senses about themselves, their society and express their attitude towards them" (Lotman 1996: 11). 
A modern view of the reconstruction of the ancient epic was offered by G. Bloom in his work "Beowulf. Interpretation", in which the reconstruction was understood by the scientist through the prism of studying the epic structure, its cyclicality and temporality, mythological and historical components, Christian and pagan elements semantics, and also irony was emphasized as the main stylistic element (Bloom URL: books.google.com.ua/books?id=9Ks8nj3BGEQC\&pg=PA32\&lpg=PA32\&dq=Bloom + H. + Beowulf.+Interpretation\&source).

Text fragments reconstruction is directly related to the reconstruction of its composite elements. The study of the text structure as a plurality of meanings is reflected in the works of A. P. Zagnitko and T. I. Levchenko. Authors define the text as a plurality of meanings, a set of subjects, institutions and realities.

It is important to take into account the structural text elements as well as the ability to transfer meanings, metaphors, associations, etc.

According to the scientists' research, reconstruction is an important methodological tool for modern linguistic studies. Commenting on the importance of reconstruction usage, O. M. Trubachyov predicted the further development of this phenomenon and its output beyond the classical understanding as a procedural technique of comparative and historical method. According to the scientist, reconstruction is a humanity phenomenon and acts as a source of knowledge of the ancient spiritual and material culture (Trubachyov 1988: 197-222).

The usage of the reconstruction method in the renewed sense enables to deepen the study of intrasemantic elements, that allows focusing on the disclosure of the ancient and modern language consciousness connection, reflected in the images of mass media texts in general and newspaper synoptic texts (hereinafter - NST) in particular.

In a new way the text is conceived in conditions where the borders between sciences are erased and the problem of disclosing a semiotic and informative approach to its definition and status appears. At the heart of this approach there is the idea that the culture is a way of representing and interpreting reality by its objectification throughout the text. According to $\mathrm{Yu}$. Lotman, culture is conceived as a complex organized sign mechanism, which ensures the existence of a particular collective personality of a certain group of people, who possess some intransitive instinct, common memory, unity of behavior, unity of the surrounding world modeling and unity of attitude towards it (Lotman 1996: 11-22). According to this statement, text undoubtedly acts as a cultural sign.

\section{Methods of the Analysis of Linguistic Material.}

Among the methods and methods of the study is the method of cognitive and linguistic reconstruction, which was used at various levels of the symbolic organization of newspaper synoptic texts. The aim was to represent the text as macrosign of cultural nature and reveal characteristics on the basis of the coding of historically predetermined and fixed meanings in the mind. Comparative and typological method was used for the choice of tertium comparationis, comparative interpretation of linguistic material and the establishment of common and different semantic elements of newspaper synoptic texts; contextual and interpretation method was used to establish the status of newspaper synoptic text, its significance in the social and cultural context.

\section{Newspaper Synoptic Text Content Reconstruction.}

The notion of the "text" can be defined in different ways. T. M. Nikolayeva offers such definitions: 1) text - is the linked sequence, completed and issued correctly; 2) the sequence of statements, which belong to one participant of communication; 3) piece of writing in the form of language creation (Nykolayeva 2000: 25). The following definitions do not divide the potential and realization levels, incorrectly link the text only with one participant of 
communication, do not take into account the level of informational contents, correlate the text only with the sequence of statements, secondary means of the information transmission.

One of the most controversial in linguistic plan is the newspaper synoptic text, because in its content and form the intergenerational experience is reflected concerning weather issues, that is being tried to explain through scientific astronomical, geographical, and climatic factors in modern synoptic forecasts. Such text form and content reconstruction will contribute to the disclosure of those national and cultural symbols which are covered under the new rules for presenting weather forecasts in various ethnic cultures.

The newspaper synoptic text appears in the middle of the XIX century. British researcher R. A. Martin notes that along with newspaper weather forecast there is the socalled "weather journalism", which purpose is not only the weather prediction, but the caution against possible natural disasters and the fixation of atmospheric phenomena, and also the formation of a value relation to the text itself, distinguishing its key characters (Sterling 2009). The appearance of a telegraph in 1844 and the flourishing of meteorology as a science gave an impulse to the whole section of the weather news emergence. Francis Bufort and Robert Fitssraw, the British hydrographers, contributed to the emergence of weather forecasting, which was reflected in the newspaper synoptic text.

Thus, when we define the term "the newspaper synoptic message", we pay attention to its cultural nature as well as information transmission, the attitude formation, and the key features. Due to the mentioned facts above, we define the newspaper synoptic text as a structural macrosign of cultural, mental and linguistic nature, created by representatives of media-media practices (G. Ya. Solganik), native language speakers, necessitates the implementation of a comprehensive reconstruction of its innersemantic elements. According to this fact, the study of innersemantic elements remains one of the key problems of modern cognitive linguistics.

Synoptic text is the author's text, where the personal modality dominates, which is a logical step in the attitudes formation in writing process. The newspaper synoptic texts' modality is manifested through a series of linguistic tools used in the texts of journalistic style, mainly stylistic, lexical and idiomatic. The integrated usage of these techniques, on the one hand, allows the author to make a value judgment to give information, but on the other, creates a reader's attitude to the author's language.

The analyzed techniques studied through the prism of reconstruction would help to realize that the text is a reflection of the attitude traditions to the weather and the use of stylistic devices only enhance the emotional perception of weather conditions, the intention of the author in this case is to create a positive attitude to weather conditions.

\section{Aim of the Innersemantic Element Reconstruction.}

The newspaper synoptic text is the specific reflection of people culture, their outlook and attitude to the surrounding world. Different language level units take part in their formation according to their interdependence and interaction. Reconstruction of figurative and stylistic elements on the basis of the interaction of dictionary and contextual meanings presupposes the interpretation of content and semantic features, allows decoding the ancient NST images, compiled over the centuries and actual nowadays.

The reconstruction of the innersemantic elements of the NST is aimed at identifying the stable, meaningful characteristics used to codify the historically determined and consolidated meanings in the mind, reflected in the practice of weather forecasting. The procedure for determining the meanings fixed in the consciousness involves a clear algorithm of actions that, in addition to the reconstruction of the images and meanings of the NST, is aimed at the reconstruction of the ancient vocabulary and the definition of the values that were fixed therein. Emphasizing the importance of the reconstruction of semantic elements, O. Sorokina 
observes that semantic reconstruction involves the vocabulary study according to its disciples and thematic groups, as well as the definition of the place of the vocabulary in text (context) (Sorokina URL: http://cyberleninka.ru/article/n/k-utochneniyu-soderzhaniya).

Considering text as a sign of mental nature (N. D. Arutyunova, G. A. Zolotova, O. O. Selivanova, H. Bloom, M. Halliday, W. Roider), it is easy to distinguish the main approaches represented in numerous works by scientists: according to M. A. K. Halliday theory, the text is a semantic sign and can not be defined as a certain organization, since it represents the actualization of the potential; according to A. Graymas research, the text is divided into statements, but is not their sum; according to P. Giro, the text is a collection of elements, which in system bonds acquire a qualitatively new semantic effect (Selivanova 1999: 27); according to L. A. Lisichenko and L. G. Savchenko, figurative and stylistic elements belong to the semantic elements and form a "semantic author's field". Thus, the text semantics is manifested through the system of introsemic (first of all, figurative and stylistic) elements, which in the system consists of the mental reality modeling, which is the product of author's cognition.

In view of this, the purpose of the article is to carry out the reconstruction of figurative and stylistic elements and the interpretation of the components of their semantic content.

Achievement of the set goal involves solving the following objectives:

- to perform reconstruction of figurative and stylistic elements and decode the established images based on the results;

- to study the content and semantic features of figurative and stylistic elements of the NST.

\section{Figurative and Stylistic Elements Classification.}

Figurative and stylistic elements of the NST differentiate according to the classification of the well-known scholar-linguist I. R. Halperin, who distinguished:

1. Stylistic elements based on the interaction of vocabulary and contextual meaning: 1) metaphor; 2) metonymy, 3) irony.

2. Stylistic elements based on the interaction of logical and emotional meaning: 1) epithet, 2) oxymoron.

3. Stylistic elements that provide additional characteristics of the object of the description: 1) comparison; 2) periphrasis; 3) hyperbole; 4) meiosis (Halperin 1981: 138176).

\section{Figurative and Stylistic Elements Reconstruction.}

Reconstruction of the elements of first group requires the study of their content and semantic features, which will help to find out and decode the oldest images of the NST, that are products of people consciousness compiled over the ages and still relevant.

The metaphor (from Greek "transfer", "figurative value") is defined as: poetic means consisting in the figurative word usage or phrase based on analogy, similarity or comparison, as well as the word or expression used in this way (SLT: http://www.ukrlib.com.ua); a complex figurative and semantic structure, representing a special way of cognition, carried out by generating images that arise as a result of the interaction of two diverse meanings (LSD: 382); the substitution of the usual figurative expression, semantic universality (VTSUM: 531).

Metaphors, like semantic universals, have features such as interactivity, universality and national specificity.

The processes of metaphorization take place in the field of mental-thinking practice, which deals not with real things and phenomena, but with their reflections in human consciousness. K. Zhol observes that "the emergence of a metaphor in the field of linguistic consciousness is the evidence of phylogenetic and ontogenetic maturity" (Zhol 1984: 111- 
112). Metaphors, like semantic universals, have such features as interactivity, universality and national specificity.

Metonymy (from Greek - $\mu \varepsilon \tau \omega v v \mu i ́ \alpha$ - renaming) is interpreted as: a lexical unit which meaning is transferred to the name of another object, associated with the object in the given word by its nature, the direction of semantic derivation (SLT: http://www.ukrlib.com.ua).

The metonymy as a semantic element is characterized by the following features: the inverse and irreversibility of the semantic change (reversal - nonreversible change of value).

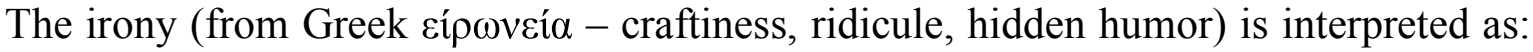
an artistic trail that expresses the mock-critical attitude to the subject of the image (SLT: http://www.ukrlib.com.ua); means of stylistic interpretation of the category of comic trail, means of emotional and appraisal criticism, conceptual category of text, mental linguocultural approach (Weise 1984: 39-41).

The irony-question (ironical question) as a subcategory of irony is determined by the features of the opposite of the interpretation, the binary character of the semantic change (SLT: http://www.ukrlib.com.ua), appealing to the reader's experience, his memory.

\subsection{Figurative and Stylistic Metaphor Reconstruction.}

Figurative and stylistic reconstruction of a metaphor will allow determining how natural phenomena and weather conditions are reflected in the people's consciousness by means of synoptic text and find out the relation associated with them.

N. D. Arutyunova divides metaphors into the following groups:

1) nominative metaphors that consist of one descriptive value replaced by another and homonymy;

2) figurative metaphors that serve the development of figurative meanings and synonymous means of language;

3) cognitive metaphors that arise as a result of the shift in the predicate words (transfer values) combining and creating polysemias;

4) generalizing metaphors (as the final result of the cognitive metaphor), erasing in the lexical meaning of the word as the boundary between the logical order and stimulate the logical polysemy emergence.

Nominative metafors of the NST are usually represented with terms formed through a figurative rethinking of commonly used lexical units. In the course of the semantic reconstruction of the nominative metaphors of the NST we distinguish two types: on the basis of simple analogies and on the basis of conditional analogies.

Metaphors based on simple analogies of the GTS are mostly often formed by the transformation of one descriptive meaning to another: for example, Eng. "Hand": Storm chaser's first hand view (The Telegraph 2016: 21.11); Ger. "Cape" (cap): heute geschrumpften Schneekappe (Der Tagesspiegel 2013: 10.01); Pol. "Czapka": czapka snezhnaya (Gazeta IE 2006: 3. 03); Ukr. “пояс": кліматичний пояс (Ukrayinska pravda 2010: 26.08).

Metaphors based on the conditional analogies of the NST of the studied languages are formed through the rethinking of terms with the components: warm / cold, liquid / solid, that act as the established characteristics of certain weather phenomena:

1) the component "warm / cold" as the established characteristic of the air mass: Eng. With the cold air mass expected to be in place, daytime temperatures could hit as low as $37 F$ (3C), with overnight frost and sub-zero temperatures (The telegraph 2012: 26.01); Ger. Warme Luftmassen beherrschen deshalb das Bild im Norden in Canada and in Alaska, wyhrend sich in Chicago and und inere Städte im mittleren Westen der derität der derit undefined by Nordpol (Der Tagesspiegel, 2014: 06.01); Pol. Na przeważajacym obszarze Polski ma być $w$ miare słonecznie $i$ bez opadów. Co więcej, napłyna do nas ciepłe masy 
рожіеtrza (Fakt 2016: 18.11); Ukr. На Украӥну насувається тепла повітряна маса (Ukrayinska pravda 2014: 14.04);

2) the component "warm / cold" as the established characteristic of the atmospheric front: Eng. Siberian cold front sweeps across Europe, bringing record low temperatures (The telegraph URL: http://www.telegraph.co.uk); Ger. Am Montag erreicht eine russische Kaltfront Berlin (Der Tagesspiegel, 2017: 6.01); Pol. Przewaga chmur, okresami deszcz od niedzieli do wtorku, to strefy frontów, które dadza początek chłodniejszej adwekcji północnozachodniej i pótnocnej. (Fakt 2016: 30.09); Ukr. Таку погоду в Украӥні обумовить холодний атмосферний фронт, щзо переміщається із заходу на схід (Ukrayinska pravda 2012: 16.08);

3 ) the component "strong / light" as an established characteristic of precipitation: Eng. The wintry conditions claimed their first victim at the weekend as a walker fell more than 650ft after slipping on the "iron-hard" snow in the Cairngorms (The Telegraph 2009: 01.01); Germ. Regen und zum Teil kräftige Gewitter bestimmen an diesem Montag das Wetter in Deutschland (Der Tagesspiegel 2007: 2.07); Pol. Pierwsze wiosenne burze i lekki deszcz - na południu (Fakt 2011: 17.02); Ukr. Напередодні на Житомиршині вирував сильний буревій, у Хмельницькій області випав сильний град (Ukrayinska pravda 2016: 18.07);

4) the component "long / short" as the established characteristic of the forecasting period: Eng. British scientists are believed to have developed the world's best long-term weather forecasting model (Telegraph 2014: 1.04); Ger. Wetter Deutschland Wettervorhersage Tag 15 (Der Tagesspiegel URL: http://www.tagesspiegel.de); Pol. Jak wynika z 16-dniowej prognozy pogody (Fakt 2016: 2.10); Ukr. Довгостроковий прогноз погоди від науковиів-метеорологів (Dovhostrokovyy prohnoz pohody vid naukovtsivmeteorolohiv URL: http://ukr.media).

A result of figurative metaphors' semantic reconstruction is determined by the fact that the metaphor in this case is a resource to the signs of living things that are applied during the phenomenon of weather development: Eng. Rain was a frequent visitor that season (The telegraph URL: http://www.telegraph.co.uk); Ger. Regen war ein häufiger Besucher im Winter (80); Pol. Wiosna dziewczyna pojawi wkrótce (Aargauer zeitung 2016: 11.08); Ukr. Красуня-зима прийде до нас в гості раніше, ніж ми иього чекаємо (Syohodni URL: http://www.segodnya.ua).

The cognitive metaphor semantic reconstruction of the NST allows distinguishing the following three types: metaphors based on transference of human features on a weather phenomenon, metaphors based on the transference of synesthesia phenomena, metaphors based on the time signs transference.

The NST metaphors on the basis of the actions transfer "from the creatures to the weather changes", are realized through verbs and verbal forms with the meaning of motion, demonstration, and speech:

1) through the verbs with the meaning "to go, to come": Eng.: More showers to come today (The telegraph 2017: 7.02); Ger. Regen geht der Kirsche unter die Haut (Der Tagespiegel 2012: 21.07); Pol. Rok później zima urzędowała bardzo długo na wschodzie Polski (Aargauer zeitung 2016: 11.08); Ukr. На Андрія в Украӥну прийдуть морози (Ukrayinska pravda 2009: 12.12);

2) through the verbs with the meaning "to travel, to reach": Eng. As the cloud traveled across the African coast, the airflow was veered southherly, carrying the dust northward above Portugal, northern Spain and the Biscay Bay, before it eventually reached the southern Britain on Wednesday afternoon (Dovhostrokovyy prohnoz pohody vid naukovtsivmeteorolohiv URL: http://ukr.media); Ger. Wolken ziehen über die Stadt, der Regen bleibt 
aus (Der Tagesspiegel 2007: 12.11); Ukr. У штаті Раджастан температура сягнула позначки 51 градус із плюсом за Цельсієм (Dovhostrokovyy prohnoz pohody vid naukovtsiv-meteorolohiv URL: http://ukr.media);

$3)$ through the verbs with the meaning "to fall": Eng. In fact, much of the rain that falls in the UK starts off as snow, even in high summer (The Telegraph 2014: 3.04); Ger. Mittags ziehen erste Wolken auf, aus denen dann, vielleicht, ein paar Flöckchen fallen könnten (Der Tagesspiegel 1999: 16.11); Pol. W środę rano po raz pierwszy tej jesieni $w$ Warszawie zacząt padać śnieg (Fakt 2016: 9.11); Ukr. Під кінець тижня сніг випаде і в Києві (Ukrayinska pravda 2016: 10.10);

4) through the verbs and verbal forms with the meaning "to bring": Eng. Storm Angus is bringing wet weather elsewhere with the winds expected to be strengthened in the coming hours (The Telegraph 2016: 21.11); Ger. Die Wärme führt dazu, dass die Niederschläge mehr Regen als Schnee bringen und die die Schneedecke früher abschmilzt (Der Tagesspiegel 2015: 3.03); Pol. O ile temperatura $w$ nadchodzacy weekend utrzyma sie jeszcze w przedziale od 4 do 9 stopni $C$, to od poniedziałku będzie się zdecydowanie obniżá, a przejście przez nasz kraj frontu atmosferycznego przyniesie opady śniegu íśniegu z deszczem (Fakt 2016: 26.11); Ukr. Квітень не принесе ніяких неочікуваностей в плані погодних умов (Sylna Ukrayina. URL: http://sylnaukraina.com.ua);

5) through the verbs and verbal forms with the meaning "to drop / to jump": Eng. True, there was one short spell, July 4-8, when the temperature climbed above $30{ }^{\circ} \mathrm{C}$ over a wide area, and readings of $33.3{ }^{\circ} \mathrm{C}$ were logged on July 5 in London and Norfolk (Coventry Telegraph, URL: http://www.coventrytelegraph.net); Ger. Klettert das Thermometer auf die 25 Grad oder darüber springen (Der Tagesspiegel. URL: http://www.tagesspiegel.de); Pol. Nagły spadek temperatury, czy wręcz załamanie pogody, spowodowane jest połaczeniem wyż panującego nad Polska (Fakt 2016: 8.08) Ukr. [...] i настане довгоочікуване літо температура підскочить до +25 градусів (Ukrayinska pravda 2016: 18.07);

6) through the verbs with the meaning "to speak, to note, to report": Eng. The report from Grindelwald remarked [...], The report from La Plange spoke of [...] (The Sunday Telegraph 2003: 2.03); Ger. Ski-Club sagte, dass das Wetter [...] (Der Tagesspiegel. URL: http://www.tagesspiegel.de); Pol. W naszych prognozach pogody umieszczamy informacje o przedziałach czasowych, których dotyczy wysokość przewidywanych opadów atmosferycznych (Gazeta IE 2006: 3.03); Ukr. Як повідомляє Гідрометиентр (...) (Ukrayinska pravda 2016: 18.07);

7) through the verbs with the meaning "to show, to demonstrate": Eng. The thermometer has shown $24{ }^{\circ} \mathrm{C}$ [...] (The Sunday Telegraph 2003: 2.03); Ger. Fast 35 Grad zeigt das Thermometer an (Der Tagesspiegel 2016: 13.11); Pol. Temperatura wynosi od minus 9 stopni miejscami na wschodzie do minus 1 stopnia miejscami na zachodzie (Tvoja pogoda. URL: http://www.Tvoja pogoda.pl); Ukr. Удень термометр покаже +28 [...] +30 градусів, місиями до +35 тепла (Ukrayinska pravda 2012: 16.08).

Often, metaphorical transitions are subjected to nominations of visual and tactile sensations, the usage of which creates vivid dominant images, helping the reader to fully imagine the weather phenomenon:

1) visual sensations: Eng. Spring days come with dry weather and bright sunshine (The Telegraph 2011: 07.04); Ger. Am Mittwoch und Donnerstag ist es in der Nordhälfte überwiegend stark bewölkt, wobei im Norden vereinzelt noch etwas Regen fällt (Der Tagesspiegel 2015: 9.11); Pol. We wschodniej i południowej części kraju pokrywa białego puchu miała od 15 do $20 \mathrm{~cm}$, ale zaspy śnieżne przekraczały miejscami pół metra wysokości (Aargauer zeitung 2016: 11.08); Ukr. Перший справжній сніг уже ліг на полях Київської 
та Хмельнищької областей, надалі очікується його утворення $і$ на решті території (The Sunday Telegraph 2003: 2.03).

2) tactile sensations: Eng. The weather experts said there was "exceptional warmth across the Territory" last year (Daily Telegraph 2013: 7.11); Ger. Die Behörden sprechen von einem "ungewöhnlich kalten Wetter" (Der Tagesspiegel, 2017: 6.01); Pol. Wszystko przez chłodny front atmosferyczny nasuwajacy znad Battyku (Fakt 2013: 31.10); Ukr. 3начнi морози прийдуть внаслідок уторгнення холодних повітряних мас із північного сходу (Silski Visti 2014 URL: http://www.silskivisti.kiev.ua/19182/index.php).

The usage of such metaphors in the NST allows the reader to experience the weather forecast scenario in advance, creating the impression of transferring into the future, accompanied by a different emotional background: positive - with expected warming, increasing temperature; negative - with undesirable cooling, lowering the temperature.

The usage of time orientation features to characterize the seasons and the type of change is inherent in the NST metaphor. Such combinations often include an estimation reflected in such semantic universalities as "early" and "late":

1) time marker "early" as the phenomenon of nature, the state of the weather: Eng. Earliest spring brought daffodils out 4 weeks early (Coventry Telegraph URL: http://www.coventrytelegraph.net); Ger. Früher Sommer, schlechte Ernte (Bild URL: http://worldmags.net/146738-bild-25-august-2016.html); Pol. Jesień przychodzi wcześnie tego roku! (Aargauer zeitung 2016: 11.08); Ukr. Харківський бабак-синоптик пророкує ранню весну (Ukrayinska pravda 2016: 2.02);

2) temporal marker "late" as the phenomenon of nature, the state of the weather: Eng. The Met Office can now predict winter weather one year in advance [...] and then a transition to cooler, dryer conditions during late winter (The telegraph 2016: 17.11); Ger. Denn der Spätherbst beschert uns in seinen letzten Zügen noch in quicken ges Österreich einen sonnigen, milden und vor allem trockenen Start ins Wochenende (Wolfenbütteler zeitung URL: http://www.wolfenbuetteler-zeitung.de); Pol. Późna jesień mieni się żółciq i pomarańczem, jednak, gdy zza chmur wytania się słońce, drzewa wyglądaja jakby byly pozłacane (Aargauer zeitung 2016: 11.08); Ukr. Пізня весна та спекотне літо прийдуть 3 дощзами (Dovhostrokovyy prohnoz pohody vid naukovtsiv-meteorolohiv URL: http://ukr.media).

The reconstruction of the generalized metaphor of the NST testifies that the generalizing metaphor is the least used stylistic device in the NST of the studied languages. The generalizing metaphor is often transmitted through the following lexical units:

1) "grits" used with the aim of transferring signs of flowingness to the snow form precipitation: English. snow grits (The Telegraph 2016: 21.11); Ger. Schnee Grütze (Der Tagesspiegel URL: http://www.tagesspiegel.de); Pol. śniegowa kasza (Gazeta IE 2006: 3.03); Ukr. сніжна крупа (Ukrayinska pravda 2009: 12.12);

2) "snow cover", "blanket" creating a visual image of the earth cover: Eng. After a drought that lasted for 50 days, the snow cover in some lower French resorts was reduced to ribbons of artificial snow surrounded by rocks and grass. (The telegraph 2016: 22.12); Ger. Kais Kolumne: Geschlossene Schneedecke Anfang Januar (Der Tagesspiegel URL: http://www.tagesspiegel.de); Ukr. Сніжна ковдра вкриє Україну (Sylna Ukrayina URL: http://sylnaukraina.com.ua);

3) "eye", which creates a vivid and at the same time dangerous image in readers' imagination: Eng. Eye of the Storm: Inside a Hurricane (Coventry Telegraph 2015: 17. 04); Ukr. 25 листопада Київ опинився в центрі “ока бурі" (Silski Visti URL: http://www.silskivisti.kiev.ua/19182/index.php); 
4) the "line" most often used in combination with the "snow": Eng. But springlike temperatures mean even here the snow line is far higher than usual (The telegraph 2013: 28.11); Ger. Dort sind die Zusammenhänge so simpel wie erwartet: Je kälter es wird und je tiefer die Schneegrenze sinkt (Der Tagesspiegel 2013: 10.01); Pol. Linie śniegu można znaleźć wokót młodych gwiazd (Aargauer zeitung 2016: 11.08).

Comparison of the NST of English, German, Polish and Ukrainian proves that synoptic texts are rich in metaphorical methods, which allows us to conclude that the diversity of images and transmissions are fixed in the minds of the people in relation to the weather prediction.

\subsection{Figurative and Stylistic Metonomy Reconstruction.}

NST contains a number of elements of methonymic transformation, among which we allocate the following models of transformation:

1) from the name of the weather phenomenon to the name of the action result: Eng. Some afternoon sun brings warming up to 36 C! (warming - warming, increasing the temperature of air) (Coventry Telegraph URL: http:/www.coventrytelegraph.net/); Ger. In einer Woche eine starke Erwärmung in 10hpa (Erwärmung - warming, increase in air temperature) (Der Tagesspiegel 2015: 3.03); Pol. Zimno pochodzi, pochmurno i deszczowo (Zimno pochodzi - cold weather, decrease in temperature) (Tvoja pogoda. URL: http://www.Tvoja pogoda.pl); Ukr. 28-29 листопада в Украӥні очікується похолодання $i$ мокрий сніг (Syohodni URL: http://www.segodnya.ua);

2) from the name of the action to the name of the object of action: Eng. The forecast office is predicting the future state of an object or phenomenon based on the analysis of current characteristics (The telegraph 2016: 17.11); Ukr. Прогноз погоди на 8 лютого (Ukrayinska pravda 2016: 2.02);

3 ) from the name of the part of the weather phenomenon to the name of the whole phenomenon of weather: Eng. From today onwards, weather will remain unsettled with many resorts receiving welcome falls of new snow over the next few days (The Sunday Times 2005: 12.12) (Falls - about snowfall); Ger. Eigentlich müssten sich die Flocken in Tropfen verwandeln (Der Tagesspiegel 2007: 12.11) (Flocken in Tropfen - snowfall and rain); Pol. Wydaje nam się, że im większe bąble pojawiajace się na ich powierzchni podczas uderzenia kropli, tym dtużej będzie padać (Tvoja pogoda URL: http://www.Tvojapogoda.pl); Ukr. $A$ разом із першими дощовими краплями впаде і атмосферний тиск, який дотримається низьких позииій до кіния вихідних (Coventry Telegraph URL: http://www.coventrytelegraph.net).

The usage of metonymy in the NST is associated with cognitive processes that took place much earlier when, as a result of displaying one linguistic unit in consciousness, another meaning appeared. When creating the GTS, the author operates these linguistic units already in the finished form.

\subsection{Figurative and Stylistic Irony Reconstruction.}

Reconstruction of irony as a figurative and stylistic element allows us to distinguish the following semantic models:

1) violation of the ritual and habitual everyday lifestyle: Eng. Reports of "white rain" from Hampshire and Sussex were broadcast on the radio around $5 \mathrm{pm}$, and although the subsequent heavy downpour diluted deposits, the following morning many people noted light colored dust on their cars (The Sunday Telegraph 2003: 2.03); Pol. Pierwsze przejaśnienia zaczna się pojawiać $w$ nocy ze środy na czwartek (8/9.02) w zachodniej połowie kraju. Na nic się nam jednak nie zdadza, bo w nocy słońca nie ujrzymy (Gazeta IE 2006: 3.03); Ukr. B 2017 рочі очікується куди більший рівень морозів, ніж у минулих роках. Синоптики 
впевнені, щзо зима 2016-2017 в Україні якщзо і буде бити температурні рекорди, то виключно зі знаком мінус (Prohnoz URL: https://www.obozrevatel.com);

2) the representation of the obscurity of the attitude toward the weather phenomena: Eng. By this time dust clouds had been overtaken by proper clouds associated with an advancing cold front, and light rain falling from these clouds washed the dust out of the atmosphere, depositing muddy splashes on vehicles and destroying any wash that was left out to dry the brisk southerly breeze (The telegraph. URL: http://www.telegraph.co.uk); Pol. W sobotę (30.01) mocno padać będzie na zachodzie i pótnocy kraju, tam też spodziewamy się porywów wiatru do 50-60 km/h (Aargauer zeitung 2016: 11.08).

Irony substitution is the ironic question by which the author successfully represents a generalized-valued attitude to weather phenomena. Irony questions are mostly often used in the most segmented text part in the title. Using this figurative and stylistic element in the headings is an indication that the author's headings are intended as aesthetic marks bearing the emotional and appraised color of the author's attitude.

The English NST is characterized by ironic questions about weather phenomena and the function of the author's commentary: Will British weather provide reliable electricity?, The big freeze, 2009-10 unprecedented or what?, Winter 2006-2007 - why so warm? (Coventry Telegraph URL: http://www.coventrytelegraph.net)

For German synoptic texts, the usage of ironic questions is not typical, since they involve the reader's opinion with the author's appreciating attitude, which is inadmissible for the German media, since the reader must form his own opinion based on the offered facts.

For Polish NST, ironic questions are typical for headlines, but they are negatively appreciated by the author's attitude to the weather phenomena, especially the expression of regret due to unfavorable weather conditions: Oto chmura, która zabrała nam Słońce. Kiedy ustama? (Gazeta IE 2006: 3.03)

For the Ukrainian NST, as well as for the German ones, it is not indicative to use the ironic question in the headings, but they are used in the text: Чи дійсно буде вже зима? (Ukrayinska pravda 2009: 12.12).

\section{Reconstruction of Stylistic Elements Based on the Interaction of Logical and Emotional Meaning.}

Reconstruction of the epithet as the main figurative and stylistic element of the NST revealed the usage of signs of the same semantic plan.

Signs of the same semantic plan, represented by lexical units which denote:

1) colour: Eng. Widespread hailstone, heavy rain and gusts of wind swept across Britain today, creating dark and gloomy gray skies (The Sunday Telegraph 2003: 7.03); Ger. Im Winter zeigt sich Berlin als graue Stadt an der grauen Spree. Und der Himmel? Auch grau (Der Tagesspiegel URL: http://www.tagesspiegel.de); Pol. Mróz, ale niewielki. Śnieg, ale $z$ deszczem. Stońca mało, a niebo szare (Gazeta IE 2006: 2.02).

Negative author's assessment of weather phenomena in the form of rain, mist is often transmitted through the grey colours, which reflect disapproving relation to such rainfall.

2) weight: Eng. The arrival of 2017 will be a washout for many as heavy rain sweeps across the country after one of the driest decades in a century (The telegraph. URL: http://www.telegraph.co.uk); Ger. Nachmittag schwere regen Duschen (Der Tagesspiegel URL: http://www.tagesspiegel.de); Pol. Poza tym w marcu będzie mróz nad ranem, a za dnia śnieg z deszczem oraz ciężkie chmury dokładnie przysłaniajace słońce (Gazeta IE 2006: 3.03); Ukr. Згідно з прогнозами гідрометеоцентрів на найближчі 10 днів, в усій Галичині буде мокро, дощі не йтимуть лише кілька днів, але сонце на небі все одно заступатимуть важкі хмари (Syohodni URL: http://www.segodnya.ua); 
The image of the cloud in each people group imagination is associated with something heavy, inappropriate, as well as with the absence of the sun rather than with the rain.

3) size: Eng. However, a little rain is possible later in the afternoon and evening (The telegraph. URL: http://www.telegraph.co.uk); Ger. Es gibt kleine örtliche Gewitter (Der Tagesspiegel URL: http://www.tagesspiegel.de/); Pol. Jedynie w Ełku może w okolicach 26 kwietnia spaść mały deszcz (Gazeta IE 2006); Ukr. Завтра на Рівненщині очікується дрібний дощ (Syohodni URL: http://www.segodnya.ua);

4) duration: Eng. The sunshine this afternoon is going to be welcome, but not longlasting (The telegraph. URL: http://www.telegraph.co.uk); Ger. Lang ersehnter Regen (Der Tagesspiegel); Pol. Wyjątkowo długa i silna fala upalałów (Gazeta IE 2006: 3.03); Ukr. 3 3-го по 7-е - невеликі дощі (Syohodni URL: http://www.segodnya.ua);

5) temporality: Eng. The other hot spells were in late-June and early-July (The Sunday Telegraph); Ger. Mit etwas Glück beschert uns der Frühherbst einen wunderschönen Altweibersommer und Nochmal Reichlich Obst (Der Tagesspiegel URL: http://www.tagesspiegel.de);

6) mental characteristics: Eng. August, they say, is the silly season - a month in which nothing serious happens and there is no real news to report (The telegraph. URL: http://www.telegraph.co.uk); Ger. ordentlich durcheinander Frühherbst (neat chaos about the beginning of the fall) (Der Tagesspiegel URL: http://www.tagesspiegel.de); Pol. Wiatr południowo-wschodni, w zachodniej połowie kraju umiarkowany i dość (Gazeta IE 2006: 3.03); Ukr. В Україні остаточно погіршиться погода на вихідні: прогноз синоптиків невтішний (Syohodni URL: http://www.segodnya.ua).

8) attitude (good / bad): Eng. The Met Office issued severe weather warnings for many parts of Britain (The telegraph URL: http://www.telegraph.co.uk/); Ger. Schlechtwetter Locations in Berlin (Der Tagesspiegel).

Oxymoron was not found in synoptic texts of the studied languages. This figurative stylistic technique is not typical for weather forecasting.

\section{Reconstruction of Stylistic Elements that Provide Additional Characteristics of the Object of the Description.}

8.1. Reconstruction of Comparison.

The English NST comparison is most commonly found in subtitles, for example: Washday blues as desert dust; and in the text itself: the grass turned brown, the courts became arid and dusty, the spectators dropped like flies on the hottest afternoons, and it was not little wonder that the players themselves did not suffer more from the heat (The telegraph URL: http://www.telegraph.co.uk).

There were no comparisons found in the German and Polish NST, which are related to the laconic synoptic texts and lack of ambiguity in the interpretation of weather phenomena.

In the Ukrainian NST, the comparison is not figurative; it has a purely pragmatic character, mostly found in the text itself, as an appeal to the reader's memory: Ukr. Взагалi нинішня осінь, на відміну від торішньої, на більшій частині території відзначилася досить посушливими умовами, надто на півночі країни (Syohodni URL: http://www.segodnya.ua).

\subsection{Reconstruction of Hyperbole.}

One of the way to express exaggeration and at the same time intensification in order to increase the significance of the NST is the usage of the following semantic features:

1) active usage of words of assertive tone or categorical quantifiers: Engl. Much of Britain should enjoy sunshine for the next couple of days as research in the wettest summer for 100 years (The telegraph URL: http://www.telegraph.co.uk); Pol. Na termometrach całkiem przyjemna temp. od 4 na pótnocnym-wschodzie do 5-7 st. C na pozostatym obszarze 
(Gazeta IE 2006: 3.03); Ukr. За оцінками метеорологічних станиій, більшість посівів озимини у слабкорозвиненому стані, що означає нечіткі перспективи для майбутньої перезимівлі (Syohodni URL: http://www.segodnya.ua);

The usage of the above mentioned lexical units is characterized by a transversal semantic diffusion, so they are referred to as universal quantifiers, which cause the loss of object identification, which is associated with the description of the approximate results of weather phenomena, temperature regime, forecasts of experts.

2) active usage of the words of negative tonality: English. Here, there was no relaxation of the cold weather over the Christmas holiday (The telegraph. URL: http://www.telegraph.co.uk); Ger. Wie lang die Let's talk about it, you know, Wetterexperten noch nicht absehen (Der Tagesspiegel URL: http://www.tagesspiegel.de); Pol. Brak świadomości zagrożenia ze strony żywiołu, jakim jest woda, sprawia, że niepotrzebnie narażamy się na niebezpieczeństwo (Gazeta IE 2006: 3.03); Ukr. Зима також буде вологою, $i$ не очікується взагалі ніяких погодних катаклізмів, як було в Європі минулого року (Syohodni URL: http://www.segodnya.ua)

\section{Conclusions and Perspectives of Further Research.}

The newspaper synoptic text is the specific reflection of people culture, their outlook and attitude to the surrounding world. Different language level units take part in their formation according to their interdependence and interaction.

We define the newspaper synoptic text as a constructive macrosign and we conclude that: 1) the NST provides a reflection of the people culture, its worldview, its attitude toward the surrounding world and natural phenomena, which manifests itself at different text levels: structural, semantic, syntactic; 2) the design of a newspaper synoptic message is characterized by a clear sequence of information blocks, since it is prescribed by the author in advance and is a guide for the reader; 3 ) in the semantics of the text through the external and internal elements the mental traits of the people are manifested, through the syntax and syntactic figures is reflected the linguistic design of the text and coded author's estimates.

The comparison of synoptic texts of four languages showed that English synoptic messages are more expressive, have more stylistic devices, although they have the probabilistic character, unlike the Polish messages are more laconic, concrete, and their aim is only informing and making the particular attitude and reaction.

\section{References}

Aytov, S. Sh. (2014). Phylosophy of culture Yu. M. Lotman: cognitive dialogue semiotics and historical anthropology purpose. Anthropological Measurements of Philosophical research. Dnipro. 6. 32-42.

Aytov, S. Sh. (2015). Cognitive dialogue of East European philosophers of the first half of XX C. and methodological approach of historical anthropology. Anthropological Measurements of Philosophical Research. Dnipro. 8. 97-105.

Boldyrev, N. N. (2006). Yazykovye katehoryy kak format znanyya [Language categories as knowledge format]. Voprosy kohnytyvnoy lynhvystyky. 2. 5-22.

Bulakhovsky, L. A. (1954). Fonetychni i morfolohichni pivdennorusyzmy v staroruskykh pamyatkakh XII$X I V$ st. [Phonetic and morphological southern russizms in the Old Russian memoirs]. Pratsi Kyyivsk. derzh, un-tu, Humanitarni nauky. 133.

Cherkhava, O. O. (2015). Fenomen rekonstruktsiyi u linhvokomparatyvistytsi doby strukturalizmu [The phenomenon of reconstruction in comparative linguistics of the age of structuralism]. Visnyk Kyyivskoho natsionalnoho linhvistychnoho universytetu. K. : Vyd. tsentr KNLU. 18. 157-164.

Crystal, D. (2006). Language and the Internet. Retrieved from https://books.google.co.uk

Delva, O. V. (2014). Rekonstruktsiya modalnykh svitiv: kohnityvno-komunikatyvnyy aspekt [Modal worlds reconstruction: cognitive and communicative aspect]. Nova filolohiya. 64. 30-34.

Dronova, L. P. (2012). Rekonstruktsyya v komparatyvystyke y kohnytyvno-oryentyrovannoy lynhvystyke [Reconstruction in comparativism and cognitive and oriented linguistics]. Retrieved from http://philology.ru /linguistics1/dronova-12.htm 
Dyakov, A. S. (2000). Osnovy terminotvorennya: semantychni ta sotsiolinhvistychni aspekty [Fundamentals of Terminology: Semantic and Sociolinguistic Aspects]. K. : Vyd. dim "KM Academia". 218.

Gensitskiy, Yu. D. (2016). Formation of Media Science infrastructure big data science in the age of high electronics. Anthropological Measurements of Philosophical Research. Dnipro: Vyd. 9. 89-95.

Halperin, I. R. (1981). Tekst yak obyekt linhvistychnoho doslidzhennya [Text as an object of linguistic studies]. M. : Nauka. 144.

Hudson, G. (1999). Essential introductory linguistics. Retrieved from: https://www.abebooks.co.uk/booksearch/title/essential-introductory-linguistics/author/hudson/

Hutnikova, A. V. (2013). Semantychna deryvatsiya yak zasib popovnennya vokabulyaru nimetskoyi ta ukrayinskoyi movy [Semantic derivation as a means of replenishment of the the German and Ukrainian languages vocabulary]. Naukovi zapysky Natsionalnoho universytetu "Ostrozka akademiya”. 39. 28-29.

Ivanov, V. V. (1963). K rekonstruktsyy praslavyanskoho teksta [To the reconstruction of the Slavic text]. Slavyanskoe yazykoznanye. V: Mezhdunarodnyi syezd slavystov. Retrieved from http://www.philology.ru/linguistics3/parina-09.htm

Korolyova, A. V. (2013). Novi vyklyky s'ohodennoyi komparatyvistyky i kontrastyvistyky [New challenges of contemporary comparatism and contrastive linguistics]. Problemy zistavnoyi semantyky. K. : Vyd. tsentr KNLU. 11. 9-15.

Korolyova, A. V. (2014). Kohnityvna linhvokomparatyvistyka: vid rekonstruktsiyi pramovnykh form do rekonstruktsiyi struktur svidomosti [Cognitive Linguistic: from the reconstruction of ancient language forms to the reconstruction of the structures of consciousness]. Visnyk Kyyivskoho natsionalnoho linhvistychnoho universytetu. K. : Vyd. tsentr KNLU. 17. 2. 94-102.

Kretov, P. V., Kretova O. I. (2017). Symbolic landscape of consciousness: man between representationalism, functionalism and relativism. Anthropological Measurements of Philosophical Research. Dnipro: Vyd. 12. 27-39.

Lysychenko, L. A. (2004). Struktura movnoyi kartyny svitu [The structure of the linguistic picture of the world]. Movoznavstvo. 5-6. 36-41.

Roider, Ul. (1981). Griech. thumos "Mut" - ai. dhumah "Rauch". KZ. 95.

Selivanova, O. O. (1999). Aktualni napryamy suchasnoyi linhvistyky (analitychnyy ohlyad) [Current trends of modern linguistics (analytical review)]. K. : Vyd-vo Ukr. fitosotsioloh. tsentru. 148.

Selivanova, O. O. (2002). Osnovy linhvistychnoyi teoriyi tekstu ta komunikatsiyi [The Fundamentals of Linguistic Theory of Text and Communication]. K. : TsUL. 336.

Shutova, M. O. (2014). Rekonstruktsiya faktiv etnokultury vid arkhetypiv do stereotypiv [Reconstruction of the facts of ethnoculture from archetypes to stereotypes]. Problemy semantyky, prahmatyky ta kohnityvnoyi linhvistyky. K. : Lohos. 25. 508-522.

Trubachev, O. N. (1988). Pryemy semantycheskoy rekonstruktsyy [Methods of Semantic Reconstruction]. Sravnytelno-istorycheskoe izuchenye jazykov raznykh semei. Teoryya lynhvystycheskoy rekonstruktsyy. 197-222.

Weise, G. (1984). Zur Spezifik der Intertextualitaet in literarischen Texten. Textbeziehungen: linguistische und literaturwissenschaftliche Beitraege zur Intertextualitaet [On the specificity of intertextuality in literary texts. Text relations: linguistic and literary contributions to intertextuality]. Tübingen: Stauffenburg. 39-49.

Williams, R. A. (1924). The Finn Episode in Beowulf: An Essay in Interpretation. Cambridge: Cambridge University Press. 184.

Zhol, K. K. (1984). Mysl, slovo, metafora. Problemy semantyky v fylosofskom osveshchenyy [Thought, word, metaphor. Problems of semantics in philosophical light]. K. : Naukova dumka. 301.

\section{Lexicographic Sources}

VTSUM - Velykyy tlumachnyy slovnyk ukrayinskoyi movy [Great Explanatory Dictionary of Ukrainian Language] (2005). Kharkiv: "Folio". 767.

LSD - Literaturoznavchyy slovnyk-dovidnyk [Literary dictionary reference book] (2006). K. : “Akademiya”. 752.

SLT - Slovnyk literaturoznavchykh terminiv [Dictionary of literary terms]. Retrieved from http://www.ukrlib.com.ua

FES - Filosofsky entsyklopedychnyy slovnyk [Philosophical encyclopedic dictionary] (2002). K: Abrys. 742.

\section{I l l ustrative Material}

Dovhostrokovyy prohnoz pohody vid naukovtsiv-meteorolohiv [long-term weather forecast from meteorological scientists]. Retrieved from http://ukr.media

Obozrevatel. Prohnoz. Retrieved from https://www.obozrevatel.com 
Pohoda [Weather forecast] (2009). Ukrayinska pravda. 12.12.

Pohoda [Weather forecast] (2010). Ukrayinska pravda. 26.08

Pohoda [Weather forecast] (2012). Ukrayinska pravda. 16.08.

Pohoda [Weather forecast] (2014). Ukrayinska pravda.11.04.

Pohoda [Weather forecast] (2016). Ukrayinska pravda. 2.02

Pohoda [Weather forecast] (2016). Ukrayinska pravda. 18.07.

Pohoda [Weather forecast] (2016). Ukrayinska pravda. 10.10.

Prohnoz pohody voseny 2015 roku [Weather forecast in autumn of 2015]. Sylna Ukrayina. Retrieved from: http://sylnaukraina.com.ua/

Syohodni. Pogoda [Weather forecast]. Retrieved from http://www.segodnya.ua

Syurpryzy zymy [Winter surprises] (2014). Silski Visti. Retrieved from

http://www.silskivisti.kiev.ua/19182/index.php

Eden, P (2003). The weather week. The Sunday Telegraph. 2.03. 40.

Scott, A. (2005). Weather and travel outlook. The Sunday Times. 24. 30.

The weather channel (2015). Coventry Telegraph. 2015. 17.04

The weather channel. Coventry Telegraph. Retrieved from http://www.coventrytelegraph.net

Weather (2013). Daily Telegraph. 7.11.

Weather (2009). The Telegraph. 01.01.

Weather (2011). The Telegraph. 07.04.

Weather (2012). The Telegraph. 26.01.

Weather (2013). The Telegraph. 28.11.

Weather (2014). The Telegraph. 1.04.

Weather (2014). The Telegraph. 3.04.

Weather (2016). The Telegraph. 17.11.

Weather (2016). The Telegraph. 21.11.

Weather (2016). The Telegraph. 22.12.

Weather (2017). The Telegraph. 7.02.

Weather. The telegraph. Retrieved from http://www.telegraph.co.uk/

Pogoda (2011). Fakt. 17.02.

Pogoda (2012). Fakt. 4.02.

Pogoda (2013). Fakt. 31.10.

Pogoda (2016). Fakt. 25.08.

Pogoda (2016). Fakt 30.09.

Pogoda (2016). Fakt 2.10.

Pogoda (2016). Fakt 9.11.

Pogoda (2016). Fakt 18.11.

Pogoda (2016). Fakt 26.11

Pogoda (2006). Gazeta IE 3.03.

Tvoja pogoda. Retrieved from: http://www.Tvoja pogoda.pl/

Aargauer zeitung [Aargauer newspaper] (2016). 11.08.

Bild (2014). Retrieved from: http://worldmags.net/146738-bild-25-august-2016.htm

Der Tagesspiegel [The daily level] (1999). 16.11.

Der Tagesspiegel [The daily level] (2007). 2.07.

Der Tagesspiegel [The daily level] (2007).12.11.

Der Tagesspiegel [The daily level] (2012). 21.07.

Der Tagesspiegel [The daily level] (2013). 10.01.

Der Tagesspiegel [The daily level] (2014). 06.01.

Der Tagesspiegel [The daily level] (2015). 3.03.

Der Tagesspiegel [The daily level] (2015). 9.11.

Der Tagesspiegel [The daily level] (2016). 13.11.

Der Tagesspiegel [The daily level]. Retrieved from: http://www.tagesspiegel.de/

Frankfurter allgemeine zeitung [Frankfurt general newspaper] (2014). 26.12. zeitung.de/

Wetter heute [Weather today]. Wolfenbütteler zeitung. Retrieved from: http://www.wolfenbuetteler- 


\section{Бібліографічний опис:}

Коломієць, О.М. (2018). Реконструкція образно-стилістичних елементів газетних синоптичних текстів (на матеріалі англійської, німецької, польської та української мов). Науковий часопис Національного педагогічного університету імені М. П. Арагоманова. Серія 9 Сучасні тенденцї розвитку мов. К. Вип. 17. С. 81-98. DOI: https://doi.org/10.31392/NPU-nc.series9.2018.17.07

\section{Анотація}

У статті розглядаються нові методологічні можливості прийому реконструкиії, який у когнітивній лінгвістииі почали застосовувати для виконання інших - ширших завдань, пов'язаних $з$ необхідністю відновлення структур свідомості, до яких належать і газетні синоптичні тексти (далі - ГСТ) як ментальні утворення. Здійснюється декодування внутрішньосемантичних елементів ГСТ, серед яких образно-стилістичні засоби, які базуються на взаємодії 1) словникового та контекстуального значень (метафора, метонімія, іронія), 2) основного та похідного значень (зевгма, гра слів), 3) логічного та емотивного значень (епітет, оксюморон), 4) логічного та номінативного значень (антономазія), а також ті, 5) що надають додаткової характеристики об’єкту опису (гіпербола, порівняння).

Установлено, що основним засобом ГСТ, що базується на взаємодії словникового та контекстуального значень, є метафора, у ході реконструкції якої вдалося визначити чотири їі типи: номінативні метафори, образні, когнітивні та генералізуючі. Визначено 3 моделі метонімічного перенесення, серед яких: назва явища погоди - назва результату дії, назва дії-назва об'єкта дії, назва частини явища погоди - назва чілого явища погоди, а також 2 напрями семантичного переосмислення явищ, пов'язаних із прогнозуванням погоди: порушення ритуальності та звичності повсякденного життя та репрезентачія завуальованості ставлення до зображуваних явищ погоди.

Зафіксовано, що мени продуктивними образними засобами в ГСТ досліджуваних мов є ті, що засновані на взаємодії основного й похідного значень та логічного й емотивного значень, а серед найтиповіших засобів, що надають додаткової характеристики об'єкту опису, виявлено гіперболу для вираження надмірного переживання сченарію розгортання погодних умов, та порівняння - для апелювання до досвіду та пам'яті читачів, що допомагає їм увиразнити запропоновану автором інформаиію.

Ключові слова: реконструкиія, газетний синоптичний текст, образно-стилістичний елемент, стилістичний прийом, внутрішньо семантичні елементи. 